\title{
Prim 'A' Geniture: Gender Bias and Daughter Successors of Entrepreneurial Family Businesses
}

\author{
Lynn Alison Hamilton ${ }^{1 *}$, Stefanie Ruel ${ }^{2}$, Janice Lynn Thomas ${ }^{3}$
}

Published: September 1, 2021

\begin{abstract}
Entrepreneurs establishing businesses from research and innovation eventually must consider the succession of their firms. Often the enterprise is passed to a family member to continue the vision and legacy of the entrepreneurial founder. While typically the norm of primogeniture dictates that the eldest son is the recipient, today, with changing societal attitudes toward women's leadership, daughters often find themselves as the firm leader. While some daughters report advantages, others experience significant gender bias in the successor-leader role. Using a critical realist methodology, this exploratory study used interviews from three daughters who were either the successor-leader or were in the process of becoming the successor-leader of a business founded by their father to identify mechanisms within the family, the family business and societal social structures that caused them to experience gender bias. Marxist feminist notions of patriarchy and its roots within the family structure were applied as an a priori theory to identify potential mechanisms that cause gender bias. While this 'triple patriarchy' was expected to explain the cause of gender bias, the data suggest that when daughter successors receive validation by their father, any mechanisms that may have caused gender bias are counteracted by others that enable a daughter to be accepted as the successor-leader.
\end{abstract}

Keywords: gender bias, critical realism, Marxist feminism, family business, daughter succession

\section{INTRODUCTION}

Research and innovation efforts often become commercialised as business endeavours (Baldwin et al., 2006). While it is the entrepreneur-founder who is typically associated with the enterprise, the entrepreneur's family often plays a critical role throughout its development (Anderson et al., 2005; Dyer and Handler, 1994). Early life experiences in the business founder's family of origin, family involvement in the start-up activities, employment of family members in the firm, and family members' involvement in ownership and management succession are all points where entrepreneurship and family often merge (Dyer and Handler, 1994). This intimate connection between family and business makes many endeavours based on research and innovation a family business. In all businesses, who will take over the firm's ownership and leadership must eventually be considered (Barnes and Hershon, 1989). While some businesses are sold (Martin, 2001) or dissolved, others are passed to a family member (Handler, 1994; Martin, 2001; Nordqvist et al., 2013; Wang, 2010). Our interest is in this latter connection, the point at which an entrepreneur passes their enterprise to the next generation to continue their vision and legacy.

When deciding which family member will continue the enterprise, most families follow the norm of primogeniture, which prescribes that a son, typically the eldest, is the natural successor of the family business (Allen and Langowitz, 2013; Constantinidis and Nelson, 2010; Dumas, 1989, 1998; Nelson and Constantinidis, 2017; Wang, 2010). However, with changing societal norms toward the acceptance of women as business leaders (Ahrens et al., 2015; Constantinidis and Nelson, 2010), prim 'a' geniture sees daughters more often being appointed as leaders of family firms (Cole, 1997; Constantinidis and Nelson, 2009; Dumas, 1989, 1998; Humphreys, 2013; Smythe and Sardeshmukh, 2013). While some daughters report advantages to leading their family business (Nelson and Constantinidis, 2017; Salganicoff, 1990), others experience considerable challenges, often stemming from

\footnotetext{
${ }^{1}$ Doctor of Business Administration (DBA) student at Athabasca University, CANADA

${ }^{2}$ Lecturer (Assistant Professor) in the Department for People and Organisations, Faculty of Business and Law, at the Open University, UNITED KINGDOM

${ }^{3}$ Full Professor of Organizational Analysis at Athabasca University, CANADA

*Corresponding Author: lynn.hamilton@shaw.ca
} 
gender bias (e.g., Dumas, 1989; Glover, 2014; Nelson and Constantinidis, 2017; Vera and Dean, 2005; Wang, 2010). With daughters expected increasingly to be part of the generational transfer of family businesses (Nelson and Constantinidis, 2017), it is essential to understand why they experience gender bias and, in doing so, whether and how the gender bias can be eliminated.

The cause of gender bias against daughter successors as leaders of the family firm is an under-researched area. Some research (e.g., Dumas, 1989; Haberman and Danes, 2007; Wang, 2010) suggests that primogeniture may be important. For example, when daughters are excluded from consideration as successors at the outset of the succession process, they are often unprepared for assuming the leader role (Dumas, 1989). This exclusion, in turn, contributes to the belief that the only appropriate head of the family business is a son. Other research (e.g., Constantinidis and Nelson, 2009; Hollander and Bukowitz, 1990; Salganicoff, 1990; Vera and Dean, 2005; Wang, 2010) suggests that expectations about the role of women in the family and stereotypes about women's leadership ability (Eagly, 2003; Eagly and Karau, 2002; Heilman, 2001, 2012; Schein, 2001) may lead to gender bias. However, none of these explanations considers how certain social structures may cause or counteract gender bias when daughters become leaders of their family firms. We propose, via this exploratory study, that mechanisms within the social structures of the family, the family business and society may play an important role.

Framing our study within a Marxist feminist theoretical perspective, we suggest that daughter successors experience 'triple patriarchy' whereby patriarchy (i.e., men's domination over women) embedded in the family structure, society and the organisational structure causes daughters to experience gender bias when they take over leadership from their entrepreneurial fathers. While recognising that class is an integral part of a Marxist feminist perspective, our primary focus is on Marxist feminist notions of patriarchy and its roots within the heteronormative family structure and the division of labour within the structure, in other words, how gender roles within the heteronormative family are transferred to the family business and how this transference produces and reproduces patriarchy within the organisation.

Discussed in detail in the methodology section of this paper, a critical realist approach recognises that preexisting social structures and mechanisms within social structures cause events, such as events of gender bias, that individuals experience. However, these mechanisms are not immediately identifiable because they exist deep within the three levels of social reality: the empirical, the actual and the real (Sayer, 2010). By applying a critical realist approach and its method of analysis referred to as 'retroduction' (Sayer, 2010), it may be possible to identify mechanisms at the level of the real that either cause or counteract events of gender bias observable at either the empirical or actual level of reality. We use semi-structured interviews to gather data from three daughters who inherited or are in the process of inheriting the successor-leader role from their father entrepreneur. We then use the critical realist process of retroduction to analyse the data to uncover the mechanisms within the family, society and the family business social structures that may cause or counteract gender biases against daughters when they become the family business successor-leaders.

With this exploratory study, our contributions are three-fold. First, we add a gender lens to the literature on the experiences of daughter successors in the leader role, a neglected area in entrepreneurial and family business literature. Second, we demonstrate how Marxist feminist theory and its notions of patriarchy may be applied to understand why daughters experience gender bias as leaders of their family firms. Finally, we use a critical realist approach to discover how mechanisms within the social structures of the family, society and the family business may cause gender bias and whether they can be altered or counteracted to eliminate the gender bias that daughter successor-leaders experience.

We begin by discussing what a family business is and the notion of 'familiness'. Next, we consider patriarchy as understood within Marxist feminist theory and how it influences gender bias against women in business and leadership positions. That discussion is followed by a brief review of the research focused on the challenges that daughters experience in the leader role and possible reasons for gender biases. We then move to an overview of critical realism and how retroduction will be used to uncover mechanisms that either cause or counteract gender bias against daughter successor-leaders. Next, we outline our research methodology, present the succession stories of three daughter successor-leaders, and analyse their stories. Because our focus is the effect of patriarchal influences on daughter successors and how it is influenced by heteronormative family structures, daughters from non-traditional and non-heterosexual families were excluded as participants. After discussing our results, we conclude with insights into how mechanisms that cause gender bias are counteracted by others to eliminate bias.

\section{FAMILY BUSINESS AND FAMILINESS}

While heteronormative family businesses have been described as a quaint relic or an ideological icon that 'combines motherhood and apple pie with entrepreneurial drive' (Aronoff and Ward, 1995: 121), practically, they are something quite different. First, family businesses are the oldest and most widespread organisations in the world (Aronoff and Ward, 1995), ranging in size from the 'mom and pop' corner store to some of the largest 
organisations in the world (EY and University of St. Gallen, 2019). They are also critical to the global economy, generating between 70 and 90 percent of annual global gross domestic products (GDP) and creating up to 80 percent of jobs in most countries worldwide (De Massis et al., 2018). Family businesses are also the primary structure through which entrepreneurs commercialise research and innovation efforts, with families involved throughout the life of the entrepreneurial endeavour (Dyer and Handler, 1994).

Despite their prevalence, there is no one definition of the family business (Chua et al., 1999). Structural definitions consider the amount of control held by a family (Villalonga and Amit, 2006), while behavioural definitions focus on the role of the family in determining the vision and control mechanisms used in the firm coupled with an intention that the business will survive intergenerationally (Chrisman et al., 2003; Ward, 2011). Dual approaches argue that both structure and behaviour are essential (Litz, 1995; Zellweger et al., 2012). For our research, we adopt a dual approach and consider the family business as an organisation where ownership and control are concentrated in one family, and the daughter successor received these elements due to an intentional intergenerational transfer.

The connection between the family and the business means that family businesses are strongly influenced by the family (Chua et al., 1999; Sharma, 2004). As McCollom notes, 'when one looks at a family firm, one is really looking at the interaction of two complex social systems' (1990: 251). Habbershon and Williams use the term 'familiness' to describe 'the unique bundle of resources a particular firm has because of the interaction between the family, its individual members, and the business' (1999: 11). Or, as Gherardi and Perrotta note, 'the intertwining of family and business is a defining characteristic of family business' (2016: 30). The entwined relationship of the family and the business means that family businesses are affected by the family's culture and values (Distelberg and Sorenson, 2009; Hollander and Bukowitz, 1990; Litz, 1995), with some research suggesting a family's notion about gender roles within the family may influence expectations of gender roles within the family firm (Hollander and Bukowitz, 1990). With this in mind, we now explore our theoretical framework built on Marxist feminism and triple patriarchy.

\title{
MARXIST FEMINISM AND PATRIARCHY
}

The influence of the family structure in perpetuating patriarchy is central to our application of Marxist theory (Firestone, 2003; Salganicoff, 1990; Walby, 1990). According to Marxist feminist theory, men's domination of women is caused, at least in part, by the evolution of the family structure and the delineation of roles within the household as it existed historically within a capitalist system (Firestone, 2003; Walby, 1990). As Salganicoff explains:

\begin{abstract}
[During the Industrial Revolution] home and work became geographically separate places for the first time; with this change came an increased segregation of roles based on gender. Women were confined to the house and the caring of children (...) As men working outside the home used their wages to buy goods no longer made at home, their role became increasingly circumscribed to that of provider. As this occurred, the woman's role became that of caretaker; she gave the necessary nurturance and sustenance without pay. The unfortunate result was that cash came to represent power, and women's work was devalued (1990: 129).
\end{abstract}

Even today, private (Walby, 1990) or familial patriarchy is perpetuated due to various socialisation processes that are passed down from generation to generation, establishing and supporting gender roles within the family (Sanderson, 2001). From its roots within the family, patriarchy was broadened to the public sphere, resulting in the public (Walby, 1990) or societal domination of men over women (Hartmann, 1976; Lerner, 1986; Millett, 2016; Walby, 1990). In turn, this societal patriarchy influences the expectation that a man should be the organisational leader (Eagly and Karau, 2002) and that gender bias is inherent to many organisational social structures (Kanter, 1977). In the family business context, these expectations are likely more acute as the leader is literally the patriarch of both the family and the business. Given the intimate connection between the family and business, we consider the combination of familial, societal and organisational patriarchy as triple patriarchy; the patriarchy perpetuated by each of these three social structures causes or at least contributes to the gender bias that many daughters experience when they become the leader of their family business.

\section{DAUGHTERS AND FAMILY BUSINESS SUCCESSION LITERATURE}

In line with the slow but increasing acceptance of women leaders (Akhmedova et al., 2019; Constantinidis and Nelson, 2009; Kubu, 2018), more daughters are becoming successors of their family firms (Constantinidis \& Nelson, 2009). However, until recently, most family business research was genderless (Dumas, 1989; Humphreys, 2013; Wang, 2010) or based on the assumption that both sons and daughters have similar experiences in the 
successor-leader role (Dumas, 1989; Nelson and Constantinidis, 2017). Reviewing the succession literature with a gendered lens, we see that being a daughter successor has both advantages and disadvantages. For example, Salganicoff (1990) found that daughters working in the family firm enjoy both the flexibility to raise a family and improved job security. Family businesses also offer opportunities for daughters to hold positions and have incomes better than those of women in non-family firms. Indeed, the family business is where women have a real opportunity to reach the highest positions in an organisation (Salganicoff, 1990).

Other research suggests that many daughter successors face extraordinary challenges (e.g., Constantinidis and Nelson, 2009; Vera and Dean, 2005), with one of the primary challenges being primogeniture (Dumas, 1989; Hollander and Bukowitz, 1990; Wang, 2010). Primogeniture is a societal norm that the eldest son inherits the role of family leader, the family property, and in the case of family businesses, the role of successor (Aldamiz-Echevarría et al., 2017; Cole, 1997; Dumas, 1989, 1998; Wang, 2010). Primogeniture occurs globally, across cultures, and is an implicit rule that deliberately excludes daughters as successors of the family business (Constantinidis and Nelson, 2009; Dumas, 1992; Humphreys, 2013; Martinez Jimenez, 2009; Nelson and Constantinidis, 2017).

Several authors (e.g., Aldamiz-Echevarría et al., 2017; Dumas, 1989; Glover, 2014; Haberman and Danes, 2007; Keating and Little, 1997; Martinez Jimenez, 2009; Wang, 2010) confirm that gender is often the primary factor when choosing a successor, with sons preferred and daughters seldom considered as successors of the family business. Indeed, primogeniture can lead some families to go to great lengths to avoid passing the family business to a daughter, including appointing a less-qualified son-in-law as the business leader (Lee et al., 2003), selling the business, or even, adopting a grown man to become the 'son' to take on the leader role (Mehrotra et al., 2013). Primogeniture also means that daughters are typically not expected to become the family business successor and, therefore, often miss out on the important experience, training, and social support necessary to assume the leader role (Dumas, 1989; Haberman and Danes, 2007). Without these elements, the perception of a daughter's competence to carry out the leader role is diminished, and daughters are met with scepticism about their leadership abilities. This scepticism can come from both family members (Galiano and Vinturella, 1995; Wang, 2010) and stakeholders within the business (Wang, 2010).

Another common challenge is reconciling the role of successor-leader with family-based expectations of the roles of women in the family and societal-based expectations of the roles of women in business (Constantinidis and Nelson, 2009). Dumas (1989) reported that daughter successors often experience role conflict between acting as the independent manager of the business and the role of 'daddy's little girl,' which stresses her fragile and defenceless position within the family. Daughter successors also face difficulties integrating the role of mother with the role of the leader of the family business (Salganicoff, 1990; Vera and Dean, 2005; Wang, 2010). As Salganicoff found, daughters often receive conflicting messages such as 'dedicate yourself fully to the business, but give the family children,' and 'be independent and autonomous and behave like a businessman but be dependent, take care of the family, and behave like a mother' (1990: 133). Cole (1997) confirmed this double messaging, noting that parents sometimes push daughters into producing grandchildren yet complain if the daughter neglects the business.

Several authors have specifically identified gender biases as a challenge (e.g., Cole, 1997; Dumas, 1989; Parada and Dawson, 2017; Salganicoff, 1990; Vera and Dean, 2005; Wang, 2010). Wang (2010) observes that in family businesses, the interaction of macro factors such as societal and cultural attitudes toward women, and micro factors such as the individual and family, leads to stereotyping and discrimination against the daughter. As Dumas notes, 'families need to recognize a daughter's potential, however, this may require some persistence, considering that the limited view of the daughter's potential is embedded in societal and familial norms' (1989: 43). Indeed, many daughters face an uphill battle against familial and societal attitudes that they should be at home caring for the patriarchal entrepreneur's grandchildren rather than leading his business.

In sum, while the role of the successor of a family business can be rewarding for daughters, many experience challenges based on gender bias throughout the succession process (Cole, 1997; Dumas, 1989; Parada and Dawson, 2017; Salganicoff, 1990; Vera and Dean, 2005; Wang, 2010). While some authors (e.g., Dumas, 1998; Wang, 2010) have offered suggestions as to why gender biases occur, the cause of gender biases against daughter successors has seldom been the subject of empirical analysis. In this research initiative, we seek to explore the mechanisms operating within the family, society and the family business structures that may cause gender bias against daughter successors taking on the successor-leader role.

\section{METHODOLOGY}

We used a critical realist methodology to identify the mechanisms that may cause or counteract gender bias against daughter successor-leaders. Critical realism explains the relationship between social structures and human action and how social structures affect the world in which humans exist (Sayer, 2010). Within these social structures are powers or liabilities or 'mechanisms' (Sayer, 2010) that cause events that individuals experience. Because of the 


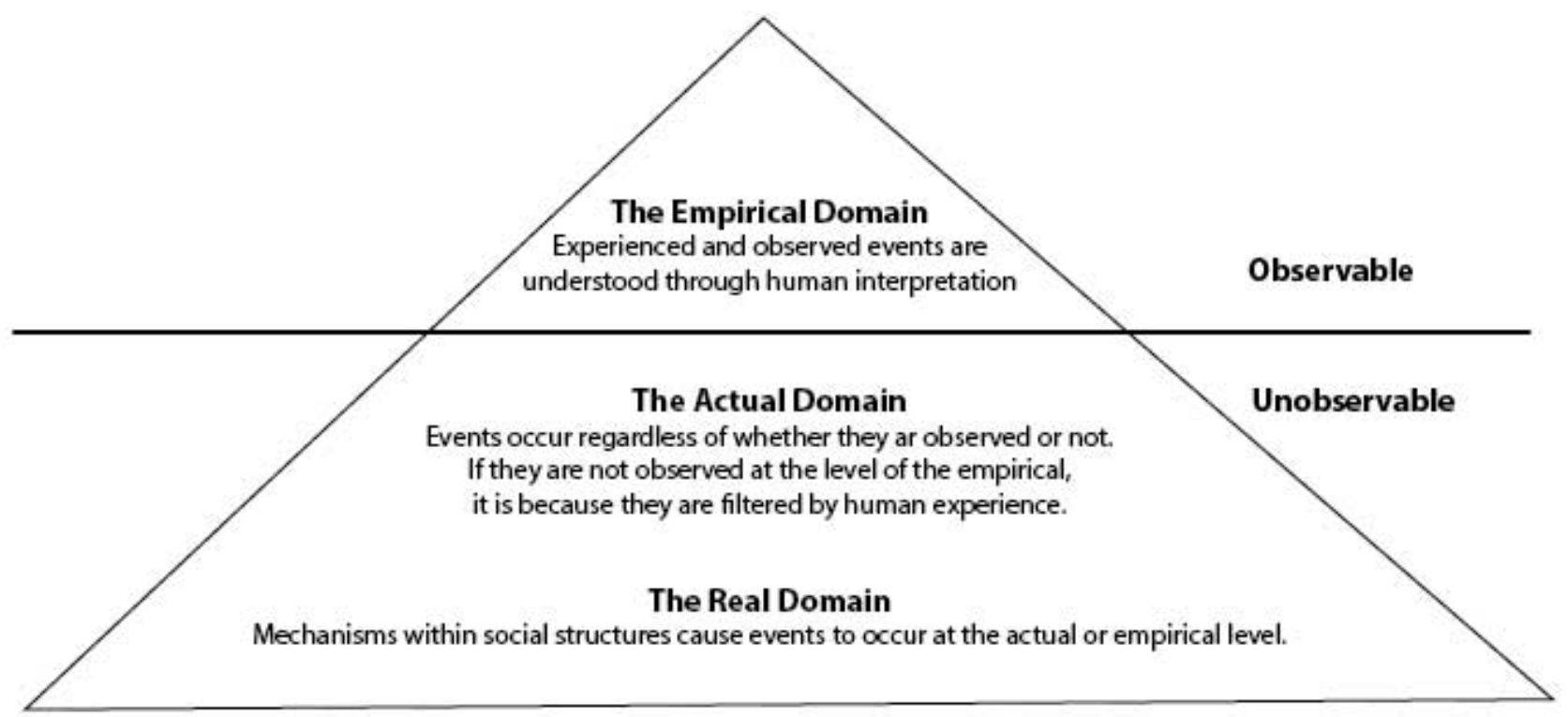

Figure 1. The three domains of reality

relationship between social structures and human awareness of them, critical realists consider the social world as having depth and that it can be understood as existing within three layers or domains of reality: the empirical, the actual, and the real (Bhaskar, 2013). The first domain, the empirical, is the world of the human experience of events (Sayer, 2010). Observations, perceptions, and sensations of reality exist within this domain (Leca and Naccache, 2006). At this empirical level, events are perceivable by both the actors who are part of a particular phenomenon and the researcher investigating it (Hu, 2018). However, events perceived by actors at this level of reality are always mediated through the filter of human experience and interpretation. Therefore, what is perceived (or not perceived) may not reveal what is actually occurring and to reveal what is actually occurring, the middle level of reality must be accessed (Fletcher, 2017).

The second or middle domain is the domain of the actual. Events happen at this level whether or not they are experienced or interpreted by humans. Since humans do not interpret events at this level of reality (Fletcher, 2017), they are often different from those observed within the empirical domain (Ackroyd and Fleetwood, 2000; Danermark et al., 2019; Fletcher, 2017). In other words, events can occur independently of the experience and perception that actors may have of them (Bhaskar, 2013). They are only transferred into the empirical domain when identified by individuals (i.e., human agency) and transformed into experience (Bhaskar, 2013).

The third domain is the domain of the real. This domain comprises social structures that contain mechanisms that generate events (Bhaskar, 2013). It is the aim of critical realism to identify and understand these causative mechanisms (Sayer, 2010). However, while events occur due to the enactment of causal powers, they sometimes act transfactually such that they are not observed or do not occur as expected (Ackroyd and Fleetwood, 2000). This is due to one or more other causal mechanisms that counteract or hide their effects (Wynn and Williams, 2012). Fletcher (2017) describes the three levels of social reality as being like an iceberg - only a small portion is observable, and much of what makes up social reality lies below the surface. This is illustrated in Figure 1 .

One of the key tenets of critical realism is that human action is both enabled and constrained by pre-existing social structures independent of humans and their interpretation (Sayer, 2010). Furthermore, these social structures tend to be enduring as they are unconsciously reproduced by humans. However, in some cases, human agency has the power to change some of these structures (Ackroyd and Fleetwood, 2000) ${ }^{2}$.

Critical realists also understand that causal mechanisms within social structures are not always observable, are not always activated, or are counteracted by other mechanisms (i.e. they act transfactually) (Ackroyd and Fleetwood, 2000; Bhaskar, 2013; McAvoy and Butler, 2018; Wynn and Williams, 2012). This is because the mechanisms that influence human behaviour exist in an open system of reality and operate in isolation from another. In other words, depending on the circumstance, the same mechanism may produce different events, and

\footnotetext{
${ }^{1}$ Adapted from Fletcher, A. J. (2017). Applying Critical Realism in Qualitative Research: Methodology Meets Method. International Journal of Social Research Methodology, 20(2), 181-194. https://doi.org/10.1080/13645579.2016.1144401

2 This is referred to as the Transformational Model of Social Activity (TMSA) by Bhaskar, R. (2014). The Possibility of Naturalism: A Philosophical Critique of the Contemporary Human Sciences (4thed.). London: Routledge. https://doi.org/10.4324/ 9781315756332.
} 
conversely, the same event may have different causes (Sayer, 2010). As will be highlighted later in our discussion of the findings, we believe that certain mechanisms may counteract the mechanisms that would typically cause daughters to experience gender bias when they become the successor-leader of their family firm.

\section{Data Collection}

Interview data were collected from three daughter participants in November of 2020. Each of the daughters inherited or was in the process of inheriting the leadership of the family business from their father entrepreneur. The companies were small or medium-sized ${ }^{3}$ private companies and operated in the areas of engineering and technology in Canada. Engineering and technology-based businesses were chosen due to their association with research and innovation efforts. The participants were recruited through the business contacts of the first author. The same author interviewed all of the participants, and the one-hour interviews took place using video conferencing. Semi-structured questions ${ }^{4}$ were developed by examining the literature on daughter succession, as presented earlier in our literature review. The responses of the participants were recorded and transcribed using the iPhone app Otter.

\section{Data Analysis}

To analyse the data, we used retroduction (Sayer, 2010). Retroduction enables a researcher to move between the three domains of reality to discover the mechanisms that may cause events to occur. Its aim is to go beyond simply recognising that something produces change to an understanding of what it is about the object that causes or enables the change (Sayer, 2010). In other words, retroduction enables the identification of causal mechanisms within social structures that may result in the empirical trends observed (Bhaskar, 2013). To be clear, causal mechanisms in critical realism are not the traditional positivist understandings of cause-and-effect that can be objectively measured. Instead, they are the inherent properties of an object or social structure that cause events to occur (Fletcher, 2017).

The retroduction process begins with the identification of demi-regularities (Fletcher, 2017). Demi-regularities are themes or patterns revealed in the empirical data worthy of further analysis to discover their causation (Bhaskar, 2013). Demi-regularities can be identified through qualitative data coding (Fletcher, 2017). Therefore, each of the daughters' succession stories was coded according to themes that emerged from the literature review, the Marxist feminist theoretical framework, and several critical realist concepts. The data was also analysed using NVivo software, which revealed additional demi-regularities. After the initial coding, the data was re-coded and broadly categorised as either structure or agency, consistent with a critical realist ontology. Examples of social structures stemming from Marxist feminist theory included the family, the family business and society. Examples of agency included expectations associated with women in leadership and gender roles within the family. While the first author coded the data, themes revealed by the data were reviewed by the other authors to control for bias.

Retroduction also involves 'abduction' or the redescription of the empirical data using theoretical concepts (Fletcher, 2017: 8). Some researchers (such as Bhaskar, 2013; McAvoy and Butler, 2018) suggest using a priori theory for this process. Initial theory enables a deeper analysis to confirm, elaborate or reject the theory, allowing a new or better explanation of reality (Fletcher, 2017). In our case, we applied Marxist feminist theory and its notion of patriarchy to understand how social structures such as the family, the family business and society may harbour mechanisms that cause gender biases against daughter successor-leaders. If our a priori theory was not supported, other explanations of the cause of gender bias would be considered (Sayer, 2010).

Given this brief overview of critical realism, our participants, and our data collection and analysis techniques, we now present a summary of each of our participants' succession stories.

\section{THE SUCCESSION STORIES}

\section{Chelsea $^{5}$}

Chelsea is white and both parents were born in Canada. After Chelsea's father was diagnosed with a severe and chronic health concern ten years ago, Chelsea became president and CEO of her family's medium-sized energy technology company. Chelsea described her father as 'an amazing leader' and respected by everyone in the organisation and the industry. In the home, Chelsea's father was also considered the leader, taking care of the family finances, and as Chelsea said, 'the big decisions,' while her mother stayed at home to raise Chelsea and her

\footnotetext{
${ }^{3}$ A small business is defined as having less than 100 employees and a medium-sized business is defined as having 100 to 499 employees. We excluded daughters leading larger organisations because of their potential lack of engagement with employees outside of the director sphere.

${ }^{4}$ Questions can be provided upon request.

${ }^{5}$ Names and company information have been changed to protect the identity of the participants in this study.
} 
younger sister. Chelsea described her upbringing as 'traditional, where the husband has a role, and the wife has a stay-at-home mom role.' However, her father believed his daughters should go to university and have a career, as his own mother did.

Chelsea's succession to leader occurred rapidly over approximately six months due to her father's unexpected illness. While the family discussed selling the business, they eventually decided that Chelsea had the education and skills to take on the leader role. According to Chelsea, she never wanted the role but agreed to it because 'I wanted to help my family. I wanted to take the burden off my dad. I wanted it to keep going'. Once her father was unable to lead, she explained, 'I struggled for a couple of years having anger and resentment. I felt like he had this big company, he worked so hard to build and create, and he literally just left me to deal with things that I had no idea how to figure out. I was abandoned'.

Chelsea described feeling like she was on a constant battlefield when she became the leader because she was continually fending off competitors trying to poach and hire her employees away. She attributed this to a perception by competitors that she was not capable of running the company. For example, she would often hear rumours such as 'you guys are going under' and noted that one competitor even took out an advertisement in a trade publication portraying her company as being run by a little girl in over her head. She summarised her first few years as a leader as follows:

I felt like I had to have this tough shell on. I didn't want to say that I don't know what I'm doing, and I need help. So, for a couple of years, I was doing my best to tread water and prove that I could do it, and we would be around.

Over time, Chelsea hired new employees that complimented her management approach, although she noted that 'we needed to work on some of the preconditioning that they had and break it down.' Competitors who had spread rumours about her company's demise eventually respected her for her business acumen. She said she was only able to continue because her dad 'believed in me,' and while her mother was initially worried about the stress of the business, she became 'an advocate and cheerleader.'

At the time of the interview, Chelsea said she loved her role and would never do anything else. Chelsea and her husband have a two-year-old son. However, because her husband's time 'isn't flexible,' she is the primary childcare provider. On the days she needed to focus on the business, her mother looked after her son. While she recognised the challenge of balancing childcare and running the business, she and her husband planned on more children.

\section{Kara}

Kara's father immigrated to Canada from India and developed a successful engineering business. Her mother immigrated from Germany to Canada and stayed at home to raise Kara, her younger brother, and her sister. Kara described her upbringing as 'very traditional', with her German mother expecting that she would marry at a young age and stay at home to raise children. Her father, however, encouraged her to get an education, stating that 'no one can take an education away from you, especially as a woman.' Growing up, Kara perceived her father as a 'figurehead' and 'patriarch' in both the family and the industry in which her family business operated.

After completing two degrees, Kara joined her family business, starting in the office answering phones. Over the years, her responsibilities increased such that she eventually became her 'father's right hand.' When Kara's father semi-retired from the company, she became CEO. Kara explained that even though she has a younger brother and sister, her father groomed her for the role by encouraging her education and mentoring her to become the leader at a young age. She said she wanted the role from the beginning and that she 'gave up a lot,' including caring for her own three children to run the business. She said her mother was supportive of her becoming the leader and took on the role of caregiver to Kara's children to enable her to go to work.

Involved in the family firm from the beginning, Kara said that her employees and industry peers always assumed she would become the successor. When asked how her siblings fit into the family business structure, she explained that 'my sister was not interested in the business, and my brother never really lived up to my Dad's expectations.' Therefore, her brother was not considered a viable successor.

Kara said that she never experienced gender biases in her role. However, she described her business industry as 'very male,' and therefore, she learned to 'push forward my views when needed and to be accurate in my job so that I can't be pushed around.' She also explained that she knew how to 'handle guys with big egos,' and they 'know that they can't pull one over on me because I have the experience and the expertise to prove myself.' She also said she made sure to include all of her degrees on her business cards, email signatures, etc. because, 'I think it is an important thing for females to make sure that you show that you have the credentials because unfortunately, otherwise, I'm just a daughter, a no one. I need to prove myself as having an education, and then through years and years of work'. 
Table 1. Case summaries

\begin{tabular}{|c|c|c|c|}
\hline & Chelsea & Kara & Ella \\
\hline \multicolumn{4}{|c|}{ The Daughter } \\
\hline Age & 36 & 57 & 37 \\
\hline Marital status & Married & Married & Divorced \\
\hline Children's ages & 2 & $25,23,20$ & 7,7 \\
\hline Childcare arrangements & Mother & $\begin{array}{l}\text { Mother when children were } \\
\text { younger }\end{array}$ & $\begin{array}{l}\text { None, occasionally a day home } \\
\text { when needed }\end{array}$ \\
\hline Education & Communications degree & Engineering and MBA degrees & Business degree \\
\hline $\begin{array}{l}\text { Years working for the family } \\
\text { business before becoming } \\
\text { leader }\end{array}$ & 4 & 25 & 4 \\
\hline $\begin{array}{l}\text { Age the daughter became } \\
\text { leader-successor }\end{array}$ & 26 & 50 & 30 \\
\hline Years as leader-successor & 10 & 7 & 8 \\
\hline
\end{tabular}

The Family Business

\begin{tabular}{llll}
\hline Industry & Energy Technology & Engineering & Mining and Forestry \\
\hline Age of business & 40 years & 41 years & 65 years \\
\hline Number of employees & 40 & 150 & 275 \\
\hline & & The Family & \\
\hline Immediate family structure & $\begin{array}{l}\text { Father, Mother, one younger } \\
\text { sister }\end{array}$ & $\begin{array}{l}\text { Father, Mother, one younger } \\
\text { brother and one younger sister }\end{array}$ & $\begin{array}{l}\text { Father, Mother and one older } \\
\text { brother }\end{array}$ \\
\hline $\begin{array}{l}\text { Roles of immediate family } \\
\text { involved in the business }\end{array}$ & Sister - Vice President & $\begin{array}{l}\text { Father - Chairman (semi-retired) } \\
\text { Brother - Vice President }\end{array}$ & $\begin{array}{l}\text { Father - Chairman (semi-retired) } \\
\text { Brother - Head of a Division }\end{array}$ \\
\hline
\end{tabular}

\section{Ella}

Ella is white and both her parents were born in Canada. Her father began a mining and forestry equipment company in the 1950s. While initially a one-person operation, it grew to over 200 employees and operated several divisions globally. Because of the nature of the business, her father was often away managing the business in remote locations, while her mother stayed at home to look after Ella and her younger brother. After completing a business degree, Ella worked for another company in a related industry for several years. When a job opened up in her family business, Ella saw it as an opportunity to learn the business and over the years, she took on increasing responsibilities. At age 37, she became the company leader while her father took a less active role.

Ella described her father as a 'legend,' with everyone in the industry and the company respecting him. Both parents had what she described as 'traditional family values.' For example, according to Ella's mother, a woman's role is to 'be responsible for the house and the kids and be dependable, always available and always there.' As for her father, Ella stated, 'he's still a bit old school and thinks that women should be at home looking after the kids.'

When asked to describe the industry she worked in, Ella said, 'it has always been male-dominated, where the men are out working and doing things, and women are expected to be at home.' She added, 'I think there are people that just grow up with that picture in mind, and therefore there is not a lot of interest in the business from females.' Ella described her most significant challenge during the succession process as coming from competitors who wondered how long she would last. She explained that 'they were almost just waiting for the failure to happen.' On the other hand, she never heard anything negative about her role in the organisation from employees and attributed it to the respect everyone had for her father.

At the time of the interview, Ella had not been going into the office due to childcare issues during the Covid19 quarantine. A single parent with seven-year-old twin boys, she spoke about the challenge of caring for children while trying to manage her business from home. She stated, 'Right now, I feel a little disappointed in myself.' She also talked about the messages she received from her parents about her business and family role. Neither parent actively encouraged her to join the business, and she felt that she had not received a great deal of support from her father as he was primarily involved with other divisions of the company. Because of this, she developed into the role on her own. Additionally, when she was expecting her twins, her father told her it was a mistake to keep working and that she 'should be at home with her boys.' She mentioned she was confused by her mother's recent remark that 'you need to be back in the office because otherwise, someone will take your job.' Ella concluded by stating, 'you just can't win, there's just no happy medium, there's no balance, it's either one or the other.'

Table 1 summarises the key information from each case to help the reader follow the participants in our analysis and discussion sections, to which we now turn. 


\section{ANALYSIS}

All three daughters stated that they did not experience gender bias in the successor-leader role. However, recognising that events are interpreted by actors (Bhaskar, 2013; Fletcher, 2017; Sayer, 2010) we looked below the level of the empirical to that of the actual and identified several events of gender bias. For example, Chelsea mentioned how she felt that her competitors saw her as 'a little girl' and therefore incapable of managing her business. Kara mentioned the need to 'handle men with big egos' and the importance of making her credentials known to gain respect from clients and competitors. Ella recalled, 'when I first started in the leader role, I'd be at the team meeting and couldn't get a word in edgeways. They would just talk right over me, plus they would do a lot of mansplaining.'

Reviewing the data further, we identified several demi-regularities. For example, all of the daughters described coming from families with 'traditional' values where the father worked, and the mother stayed home to raise children. Kara described her upbringing as 'very traditional with the expectation that I would marry at a young age and stay at home with the children.' Ella explained, 'My mom's role was being responsible for the house and the kids and being dependable and always available. Her focus was dealing with the kids in the house.' When asked about her father's notion of family roles, Ella stated, 'I think he's still a bit old school. I think he thinks that women should be at home looking after the kids.'

Despite this traditional upbringing, we observed that all of the fathers encouraged their daughters not to follow traditional familial gender role expectations. For example, Ella noted that 'my Dad always gave me the opportunity to do whatever it is that I wanted to do and said, whatever you do, I'll support it.' Chelsea also explained how her father did not expect her to conform to traditional familial roles and stated, 'My sister and I grew up knowing and thinking we could do anything. That's just fundamental to me. When I was younger, I didn't even think that I needed a husband to help take care of things' and Kara explained, 'The sky was the limit for me from my Dad's point of view.'

We also noted that all the fathers encouraged their daughters to pursue higher education before taking on the role of successor. For example, Kara described how her father encouraged her to get an education and how he told her, 'No one can take an education away from you, especially as a woman.' She added, 'My father always wanted me to get an education. It didn't matter if I didn't want to. I was going to university.' All of the fathers also wanted their daughters to gain direct work experience in the business. For example, Kara mentioned how her father saw her as 'his right hand and his backup for everything.' While the statements suggest that the fathers recognised the importance of helping their daughter achieve the credentials to overcome gender bias, they were also consistent with ideals of a Marxist working-class aspirational model.

We also observed that all the daughters had support from their mothers to carry out the leader role. This is evidenced by Chelsea and Kara's mothers helping with childcare or, in Ella's case, encouraging her to go back to work to secure her position in the firm. This also seemed to be in opposition to the traditional gender roles their mothers held in the family unit.

Having identified several demi-regularities, we used retroduction to discover potential mechanisms that may have caused the events of gender bias. This involved applying Marxist feminist theory and notions of patriarchy. Since all the daughters came from families with traditional values, we expected to find evidence of gender bias stemming from gender role expectations within the family. However, our research did not indicate this. Instead, the daughters seemed to be accepted in the leader role by the family members and employees within the family business.

To better understand the why of this, we reviewed the interviews to identify additional demi-regularities. For example, we noted that all three daughters discussed their father's power within the family, the family business, and the industry in which their company operated. Chelsea described her father as the leader of the family in terms of the financial and 'other big decisions,' and both Kara and Ella described their fathers as a 'patriarch' and a 'legend.' Ella added, 'I think there's a lot of respect out there for him for taking the risk to start the business.' On the other hand, while all of the daughters seemed to be accepted by family members and employees in the successor-leader role, all mentioned the challenges they faced from competitors outside the organisation. For example, Ella spoke of masculine competitors, 'just waiting for the failure to happen.' Kara explained how competitors were always surprised by her and stated, 'Even though they try, they can't pull one over on me because I have the experience and the expertise to be able to prove myself. I mean, as a woman, you have to.' Chelsea mentioned that when she took over, 'There was a lot of chatter. You know how long is it going to last, you know, almost just waiting for the failure to happen because of being female.' 


\section{DISCUSSION}

The intimate connection between the family and the business led us to hypothesise that gender roles within the household would create similar mechanisms within the family business. Combined with patriarchy within society (Walby, 1990) and its influence on the expectation of men as organisational leaders (Eagly and Karau, 2002), this triple influence of patriarchy would cause daughter successors to experience events of gender bias when they became the successor and leader. Instead, we found that rather than reinforcing gender roles, the family, and most significantly, the patriarchal father, acted to counteract the mechanisms that could cause gender biases within the organisation. For example, both Kara and Chelsea's fathers were highly supportive of their daughters as successor. This support came not only through encouragement to obtain education and skills but also to work with the daughter and present her as his successor. By contrasting the three cases, we can see this more clearly. Kara's father actively groomed her over a long period to become his successor, making her transition easy. Chelsea's father also appointed her as his successor. However, his illness made a lengthy and comprehensive training/mentoring period impossible, resulting in a more difficult but ultimately successful transition. In contrast, Ella did not have her father's support, with him actively discouraging her as his successor when she had children. This made her role both difficult and tenuous.

Based on these observations, we concluded that the father's message of 'my daughter is qualified and experienced, and she will be taking over my role' was a mechanism that counteracted gender bias. As the father was constructed as the respected patriarch of both the family and the business, any mechanisms that could lead to gender biases were counteracted. This counteraction, in turn, enabled mechanisms that caused the acceptance of the daughter as the leader of the family business to emerge. In other words, our analysis of the data demonstrated that validation by the father and, to some degree, support by the mother counteracted the mechanisms that would ordinarily have caused gender bias and created new mechanisms whereby the daughter was accepted as the family business successor. This finding is consistent with previous research that suggests that a father's actions either enable a daughter to be accepted as the successor or cast doubt on the daughter's capacity as the successor-leader (Dumas, 1992; Gherardi and Perrotta, 2016; Haberman and Danes, 2007).

We also believe that this finding is supported by the demi-regularity of all of the daughters describing gender bias as coming from sources outside the organisation. While prim 'a' geniture supported by the father patriarch gives cues to the employees and other stakeholders within the organisation that his daughter is acceptable in the role of leader, this message is not necessarily communicated outside the firm. Thus, daughters still experience gender bias from competitors and other outsiders to the organisation.

In observing that the daughter successor-leaders had support and validation from their fathers who were viewed as patriarchs of their family, the family business and their respective industries, we wonder whether the social structures which support patriarchy might be important. In other words, patriarchy gives fathers the power to validate their daughter as the leader and override mechanisms that cause gender bias. Indeed, the daughters' stories suggest the need for support from their patriarchal father to counteract gender bias and imply that daughters cannot counteract gender bias by themselves. Only with the support of their father, who derives power from patriarchy, can mechanisms that cause gender bias be overcome. Because of his power and domination within the family, the family business and society, the father has the ability to (re)create mechanisms that support a daughter as the family business successor and create an environment where a daughter is both validated and expected in the leader role. In doing so, prim ' $a$ ' geniture is considered acceptable, and gender bias events are eliminated.

Applying these findings within a critical realist ontology, our research not only demonstrates how generative mechanisms often act transfactually (that is to say, they do not always act as expected or even at all) but that individuals can change social structures that no longer serve them. Not only do the actions of the patriarchal father recreate the social structures within the organisation to counteract gender bias, but the daughter herself plays a role. For example, all the daughters believed education gave them credibility. As Kara stated, 'I think it is an important thing for females to make sure that you show that you have the credentials because unfortunately, otherwise, I'm just a daughter, a no one.' When the daughters obtained an education, the credibility that the education provided helped to counteract structures that supported gender bias.

Finally, focusing on the class element of Marxist feminist theory, we were aware that gender was not the only issue at play. All three daughters spoke of how their respective fathers started as 'one man' operations and grew the business to become successful. For example, they used phrases such as 'we're the largest company' or 'we are a highly successful company,' implying their fathers overcame class barriers as entrepreneurs. Furthermore, all of the daughters recognised their role in not just maintaining the success of their father's entrepreneurial endeavour but improving upon it. We concluded that the fathers were instrumental in enabling the daughters to not only overcome gender bias but to open doors for them to overcome class barriers.

We did observe key elements of intersectionality scholarship with respect to intersecting identities and the resultant order that can ensue (Crenshaw 1989, 1991; Hill Collins and Bilge, 2016). We do acknowledge this 
scholarship by sharing the intersecting idientities and some of the cultural orders that our participants experienced inside and outside the family unit. In Kara's case, for example, she did share that she was the daughter of an immigrant of Indian descent. We did wonder if Kara's father recognised that his help was instrumental for Kara to overcome not just gender bias but also bias based on a gender/ethnicity/class order. Through his messaging to Kara to 'do the right thing,' such as achieving higher education and relevant work experience, and his messaging to others within the organisation that she was his legitimate successor, Kara's father helped her to overcome these intersecting biases and the resultant order that would have otherwise marginalised her and negatively affected her success in the leader role.

\section{LIMITATIONS AND FURTHER RESEARCH}

While our study produced important exploratory results, the research's primary limitation is the small sample size. More interviews with daughter successor-leaders are necessary to confirm our findings. Discussions with the employees and family members of the daughters would also be useful to interpret better the experiences the daughter successors described. Most notably, interviews with the fathers of daughter successors would add depth to our analysis, creating a richer understanding of the three levels of reality. Comparing our research to that of daughter successors' experiences inheriting the leadership of their family business from a mother entrepreneur would also be valuable. Such a comparison may confirm whether or how patriarchy can act as both a validating mechanism that eliminates gender bias or a causative mechanism of bias. Finally, a further exploration of how patriarchy influences not just bias based on gender but how it may affect how women can overcome bias associated with intersections of class and race would be important.

\section{CONCLUSION}

A strength of the critical realist framework is that it provides insight into how we might modify social structures that no longer serve us. This article demonstrated that not only can patriarchal structures be overridden by counteracting mechanisms, but how this structural dismantling can be achieved. While patriarchy arising from role expectations within the family, society, and the family business social structure may cause gender bias against daughter successors in the leader role, our analysis found that actions of the father that validated and legitimised a daughter as successor may counteract that causal mechanism. Specifically, father entrepreneurs who embrace prim ' $\mathrm{a}$ ' geniture and actively encourage their daughters to gain education and work experience to take over their role appear to be important for counteracting gender bias. Our findings also suggest that while patriarchy may contribute to gender bias, it may also counteract gender bias by giving the father incumbent power to validate his daughter in the leader role.

This exploratory study contributes a gender lens to the literature on daughter successors in the leader role, a neglected area in entrepreneurial and family business literature. We also demonstrate how Marxist feminist theory and its notions of patriarchy may be applied to understand why daughters experience gender biases as their family firms' leaders. Finally, we reveal how a critical realist methodology can be used to identify mechanisms that cause gender bias and how those mechanisms can be counteracted by other mechanisms that eliminate gender bias, such as those that emerge when daughters are validated by their father entrepreneur. This discovery is significant as more entrepreneurs adopt prim 'a' geniture and pass the legacy of their research and innovation efforts to their daughters.

\section{REFERENCES}

Ackroyd, S. and Fleetwood, S. (2000). Realism in Contemporary Organisation and Management Studies, in S. Ackroyd and S. Fleetwood (eds), Realist Perspectives on Management and Organisations (1st ed., pp. 3-25). New York: Routledge. https://doi.org/10.4324/9780203164433-9

Ahrens, J. P., Landmann, A. and Woywode, M. (2015). Gender Preferences in the CEO Successions of Family Firms: Family Characteristics and Human Capital of the Successor. Journal of Family Business Strategy, 6(2), 86103. https://doi.org/10.1016/j.jfbs.2015.02.002

Aldamiz-Echevarría, C., Idígoras, I. and Vicente-Molina, M.-A. (2017). Gender Issues Related to Choosing the Successor in the Family Business. European Journal of Family Business, 7(1-2), 54-64. https://doi.org/10.1016/j.ejfb.2017.10.002

Allen, E. and Langowitz, N. S. (2013). Understanding the Gender Gap in Entrepreneurship: A Multicountry Examination, in M. Minniti (ed), The Dynamics of Entrepreneurship: Evidence from global entrepreneurship monitor data (pp. 31). Oxford: Oxford University Press.

(C) 2021 by Author/s 
Anderson, A. R., Jack, S. L. and Dodd, S. D. (2005). The Role of Family Members in Entrepreneurial Networks: Beyond the Boundaries of the Family Firm. Family Business Review, 18(2), 135-154. https://doi.org/10.1111/j.1741-6248.2005.00037.x

Aronoff, C. E. and Ward, J. L. (1995). Family-Owned Businesses: A Thing of the Past or a Model for the Future? Family Business Review, 8(2), 121-130. https://doi.org/10.1111/j.1741-6248.1995.00121.x

Baldwin, C., Hienerth, C. and von Hippel, E. (2006). How User Innovations Become Commercial Products: A Theoretical Investigation and Case Study. Research Policy, 35(9), 1291-1313. https://doi.org/10.1016/j.respol.2006.04.012

Barnes, L. B. and Hershon, S. A. (1989). Transferring Power in the Family Business. Family Business Review, 2(2), 187-202. https:// doi.org/10.1111/j.1741-6248.1989.00187.x

Bhaskar, R. (2013). A Realist Theory of Science. London and New York: Routledge.

Bhaskar, R. (2014). The Possibility of Naturalism: A philosopbical critique of the contemporary buman sciences (4th ed.). London: Routledge.

Chua, J. H., Chrisman, J. J. and Sharma, P. (1999). Defining the Family Business by Behavior. Entrepreneurship Theory and Practice, 23(4), 19-39. https:// doi.org/10.1177/104225879902300402

Cole, P. M. (1997). Women in Family Business. Family Business Review, 10(4), 353-371. https://doi.org/10.1111/j.1741-6248.1997.00353.x

Constantinidis, C. and Nelson, T. (2009). Integrating Succession and Gender Issues from the Perspective of the Daughter of Family Enterprise: A Cross-National Investigation. Management International, 14(1), 43-54. https://doi.org/10.7202/039138ar

Crenshaw, K. (1989). Demarginalizing the Intersection of Race and Sex: A Black Feminist Critique of Antidiscrimination Doctrine, Feminist Theory and Antiracist Politics. University of Chicago Legal Forum, (1), 139167.

Crenshaw, K. (1991). Mapping the Margins: Intersectionality, Identity Politics, and Violence Against Women of Color. Stanford Law Review, 43(6), 1241-1299. https:/ / doi.org/10.2307/1229039

Danermark, B., Ekström, M. and Karlsson, J. C. (2019). Explaining Society: Critical realism in the social sciences (2nd ed.). London: Routledge. https://doi.org/10.4324/9781351017831

De Massis, A., Frattini, F., Majocchi, A. and Piscitello, L. (2018). Family Firms in the Global Economy: Toward a Deeper Understanding of Internationalization Determinants, Processes, and Outcomes. Global Strategy Journal, 8(1), 3-21. https://doi.org/10.1002/gsj.1199

Distelberg, B. and Sorenson, R. L. (2009). Updating Systems Concepts in Family Businesses: A Focus on Values, Resource Flows, and Adaptability. Family Business Review, 22(1), 65-81. https://doi.org/10.1177/0894486508329115

Dumas, C. (1989). Understanding of Father-Daughter and Father-Son Dyads in Family-Owned Businesses. Family Business Review, 2(1), 31-46. https://doi.org/10.1111/j.1741-6248.1989.00031.x

Dumas, C. (1992). Integrating the Daughter into Family Business Management. Entrepreneurship Theory and Practice, 16(4), 41-56. https://doi.org/10.1177/104225879201600403

Dumas, C. (1998). Women's Pathways to Participation and Leadership in the Family-Owned Firm. Family Business Review, 11(3), 219-228. https:// doi.org/10.1111/j.1741-6248.1998.00219.x

Dyer, W. G. and Handler, W. (1994). Entrepreneurship and Family Business: Exploring the Connections. Entrepreneurship Theory and Practice, 19(1), 71-83. https://doi.org/10.1177/104225879401900105

Eagly, A. H. (2003). Few Women at the Top: How Role Incongruity Produces Prejudice and the Glass Ceiling, in D. van Kippenberg and M. Hogg (eds), Leadership and Power: Identity processes in groups and organizations (pp. 7993). London: Sage Publications. https://doi.org/10.4135/9781446216170.n7

Eagly, A. H. and Karau, S. J. (2002). Role Congruity Theory of Prejudice Toward Female Leaders. Psychological Review, 109(3), 573-598. https://doi.org/10.1037/0033-295X.109.3.573

EY and University of St. Gallen. (2019). Global Family Business Index 2019. St. Gallen, Switzerland: CFB-HSG.

Firestone, S. (2003). The Dialectic of Sex: The case for feminist revolution. New York: Farrar, Straus, Giroux.

Fletcher, A. J. (2017). Applying Critical Realism in Qualitative Research: Methodology Meets Method. International Journal of Social Research Methodology, 20(2), 181-194. https://doi.org/10.1080/13645579.2016.1144401

Galiano, A. M. and Vinturella, J. B. (1995). Implications of Gender Bias in the family Business. Family Business Review, 8(3), 177-188. https://doi.org/10.1111/j.1741-6248.1995.00177.x

Gherardi, S. and Perrotta, M. (2016). Daughters Taking Over the Family Business: Their Justification Work Within a Dual Regime of Engagement. International Journal of Gender and Entrepreneurship, 8(1), 28-47. https:// doi.org/10.1108/IJGE-11-2014-0044

Glover, J. L. (2014). Gender, Power and Succession in Family Farm Business. International Journal of Gender and Entrepreneurship, 6(3), 276-295. https://doi.org/10.1108/IJGE-01-2012-0006 
Habbershon, T. G. and Williams, M. (1999). A Resource-Based Framework for Assessing the Strategic Advantages of Family Firms. Family Business Review, 12(1), 1-25. https:/ /doi.org/10.1111/j.1741-6248.1999.00001.x

Haberman, H. and Danes, S. M. (2007). Father-Daughter and Father-Son Family Business Management Transfer Comparison: Family FIRO Model Application. Family Business Review, 20(2), 163-184. https://doi.org/10.1111/j.1741-6248.2007.00088.x

Handler, W. (1994). Succession in Family Business: A Review of the Research. Family Business Review, 7(2), 133 157. https://doi.org/10.1111/j.1741-6248.1994.00133.x

Hartmann, H. (1976). Capitalism, Patriarchy, and Job Segregation by Sex. Signs: Journal of Women in Culture and Society, 1(3, Part 2), 137-169. https://doi.org/10.1086/493283

Heilman, M. E. (2001). Description and Prescription: How Gender Stereotypes Prevent Women's Ascent up the Organizational Ladder. Journal of Social Issues, 57(4), 657-674. https://doi.org/10.1111/0022-4537.00234

Heilman, M. E. (2012). Gender Stereotypes and Workplace Bias. Research in Organizational Behavior, 32, 113-135. https://doi.org/10.1016/j.riob.2012.11.003

Hollander, B. and Bukowitz, W. R. (1990). Women, Family Culture, and Family Business. Family Business Review, 3(2), 139-151. https://doi.org/10.1111/j.1741-6248.1990.00139.x

Hill Collins, P. and Bilge, S. (2016). Intersectionality. Cambridge, UK: Polity.

$\mathrm{Hu}, \mathrm{X}$. (2018). Methodological Implications of Critical Realism for Entrepreneurship Research. Journal of Critical Realism, 17(2), 118-139. https://doi.org/10.1080/14767430.2018.1454705

Humphreys, M. M. C. (2013). Daughter Succession: A Predominance of Human Issues. Journal of Family Business Management, 3(1), 24-44. https://doi.org/10.1108/20436231311326472

Kanter, R. M. (1977). Men and Women of the Corporation. New York: Basic Books.

Keating, N. C. and Little, H. M. (1997). Choosing the Successor in New Zealand Family Farms. Family Business Review, 10(2), 157-171. https:// doi.org/10.1111/j.1741-6248.1997.00157.x

Kubu, C. S. (2018). Who Does She Think She is? Women, Leadership and the 'B'(ias) Word. Clinical Neuropsychologist, 32(2), 235-251. https:// doi.org/10.1080/13854046.2017.1418022

Leca, B. and Naccache, P. (2006). A Critical Realist Approach to Institutional Entrepreneurship. Organization, 13(5), 627-651. https://doi.org/10.1177/1350508406067007

Lee, K. S., Lim, G. H. and Lim, W. S. (2003). Family Business Succession: Appropriation Risk and Choice of Successor. Academy of Management Review, 28(4), 657-666. https:// doi.org/10.5465/AMR.2003.10899446

Lerner, G. (1986). The Creation of Patriarchy. Oxford: Oxford University Press.

Litz, R. (1995). The Family Business: Toward Definitional Clarity. Family Business Review, 8(2), 71-81. https://doi.org/10.1111/j.1741-6248.1995.00071.x

Martin, L. (2001). More Jobs for the Boys? Succession Planning in SMEs. Women in Management Review, 16(5), 222 231. https://doi.org/10.1108/EUM0000000005584

Martinez Jimenez, R. (2009). Research on Women in Family Firms: Current Status and Future Directions. Family Business Review, 22(1), 53-64. https://doi.org/10.1177/0894486508328813

McAvoy, J. and Butler, T. (2018). A Critical Realist Method for Applied Business Research. Journal of Critical Realism, 17(2), 160-175. https://doi.org/10.1080/14767430.2018.1455477

McCollom, M. (1990). Problems and Prospects in Clinical Research on Family Firms. Family Business Review, 3(3), 245-262. https://doi.org/10.1111/j.1741-6248.1990.00245.x

Mehrotra, V., Morck, R., Shim, J. and Wiwattanakantang, Y. (2013). Adoptive Expectations: Rising Sons in Japanese Family Firms. Journal of Financial Economics, 108(3), 840-854. https://doi.org/10.1016/j.jfineco.2013.01.011

Millett, K. (2016). Sexual Politics. New York: Columbia University Press.

Nelson, T. and Constantinidis, C. (2017). Sex and Gender in Family Business Succession Research: A Review and Forward Agenda from a Social Construction Perspective. Family Business Review, 30(3), 219-241. https://doi.org/10.1177/0894486517715390

Nordqvist, M., Wennberg, K., Bau', M. and Hellerstedt, K. (2013). An Entrepreneurial Process Perspective on Succession in Family Firms. Small Business Economics, 40(4), 1087-1122. https://doi.org/10.1007/s11187-0129466-4

Parada, M. J. and Dawson, A. (2017). Building Family Business Identity Through Transgenerational Narratives. Journal of Organizational Change Management, 30(3), 344-356. https:// doi.org/10.1108/JOCM-10-2016-0200

Salganicoff, M. (1990). Women in Family Businesses: Challenges and Opportunities. Family Business Review, 3(2), 125-137. https:// doi.org/10.1111/j.1741-6248.1990.00125.x

Sanderson, S. K. (2001). The Evolution of Human Sociality: A Darwinian conflict perspective. Lanham, Maryland: Rowman and Littlefield Publishers.

Sayer, A. (2010). Method in Social Science: A realist approach (2nd ed.). London: Routledge. 
Schein, V. E. (2001). A Global Look at Psychological Barriers to Women's Progress in Management. Journal of Social Issues, 57(4), 675-688. https://doi.org/10.1111/0022-4537.00235

Sharma, P. (2004). An Overview of the Field of Family Business Studies: Current Status and Directions for the Future. Family Business Review, 17(1), 1-36. https://doi.org/10.1111/j.1741-6248.2004.00001.x

Smythe, J. and Sardeshmukh, S. R. (2013). Fathers and Daughters in Family Business. Small Enterprise Research, 20(2), 98-109. https://doi.org/10.5172/ser.2013.20.2.98

Vera, C. F. and Dean, M. A. (2005). An Examination of the Challenges Daughters Face in Family Business Succession. Family Business Review, 18(4), 321-345. https://doi.org/10.1111/j.1741-6248.2005.00051.x

Villalonga, B. and Amit, R. (2006). How do Family Ownership, Control and Management Affect Firm Value? Journal of Financial Economics, 80(2), 385-417. https://doi.org/10.1016/j.jfineco.2004.12.005

Walby, S. (1990). Theorising Patriarchy. Oxford: Blackwell.

Wang, C. (2010). Daughter Exclusion in Family Business Succession: A Review of the Literature. Journal of Family and Economic Issues, 31(4), 475-484. https://doi.org/10.1007/s10834-010-9230-3

Ward, J. L. (2011). Keeping the Family Business Healtby: How to plan for continuing growth, profitability, and family leadership. New York: Palgrave Macmillan. https://doi.org/10.1057/9780230116122

Wynn, D. and Williams, C. K. (2012). Principles for Conducting Critical Realist Case Study Research in Information Systems. MIS Quarterly: Management Information Systems, 36(3), 787-810. https:/ / doi.org/10.2307/41703481

Zellweger, T., Kellermanns, F. W., Chrisman, J. J. and Chua, J. H. (2012). Family Control and Family Firm Valuation by Family CEOs: The Importance of Intentions for Transgenerational Control. Organization Science, 23(3), 851-868. https://doi.org/10.1287/orsc.1110.0665

Citation: Hamilton, L. A., Ruel, S. and Thomas, J. L. (2021). Prim 'A' Geniture: Gender Bias and Daughter Successors of Entrepreneurial Family Businesses. Feminist Encounters: A Journal of Critical Studies in Culture and Politics, 5(2), 29. https://doi.org/10.20897/femenc/11166

Copyright (C) 2021 by Author/s and Licensed by Lectito BV, Netherlands. This is an open access article distributed under the Creative Commons Attribution License which permits unrestricted use, distribution, and reproduction in any medium, provided the original work is properly cited. 